system consists of wandering cells, and though these rid the body of excrement quickly enough for the needs of an individual coral colony, it may well be quite otherwise in the case of a large population.

Coral reefs only maintain themselves owing to their remarkable powers of growth in the face of innumerable adverse factors, of which the power of the sea and the action of diverse boring organisms are the most potent. It is essential, therefore, that they should function with the utmost efficiency, and their powers of growth could not but be impaired were excretory products to accumulate in the tissues. But they possess in the zooxanthellæ the means whereby all excrement is automatically removed practically the moment it is formed (unlike photosynthesis, protein synthesis in plants proceeds in darkness as well as in light), and which increases as the tissues grow and the excretion of nitrogen, phosphorus, and sulphur in. creases. Coral reefs as a whole are largely a closed system, obtaining their food certainly from the zooplankton in the sea, but adding to the dissolved nutrient substances only when they dio or expel surplus zooxanthellæ. It appears by no means improbable that the Madreporaria have attained their present great importance in the economy of marine life in tropical waters owing to the aid given to them by their contained zooxanthellæ. In their absence the corals would have been unable to overcome the disadvantages inherent in the simplicity of their structure and of thoir metabolic processes.

The association between corals and zooxanthella is, therefore, essential to the plants, certainly not to individual coral colonies, but probably an indispensable factor in the necessarily exceptional powers of growth and repair possessed by the marine communities known as coral reefs.

1 Gardiner, Nature, 127, $857 ; 1931$.

? Yonge, NATURE, 123, 89; 1929.

Yonge, NatrRe, 123, $765 ; 1929$.

- Yonge, "Studies in the Phisiology of Corals", I. Feeding MechanIsms and Food. Sci. Repts., G. Barrier Reef Expedition, Brit. Mus. 1,$13 ; 1930$.

'Yonge and Nicholls, II. "Digestive Enzymes". Ibid, 1, 59; 1930

7 Yonge, III. "Assimilation and Excretion". Ibid., 1, 83; 1931

${ }^{8}$ Yonge and Nicholls, IV. "The Structure, Distribution and Physiology of the Zooxanthellæ". Ibid., 1, 135; 1931 .

- Yonge and Nicholls, $v$. "The Effect of Starvation in Light and in Darkness on the Relationship between Corals and Zooxanthellæ". Ibid., 1, 177; 1931 .

${ }^{10}$ Yonge, Yonge and Nicholls, VI. " The Relation between Respiration and the Production of Oxygen by Zooxanthellæ". Ibid., 1 (in preparation).

${ }^{11}$ Keeble and Gamble, Quart. Jour. Mier. Sci., 51, 167; 1907.

12 Boschma, Proc. Akad. Wet. Amst., 27, $13 ; 1924$.

${ }^{13}$ Boschma, Biol. Bull., 49, 407; 1925.

14 Boschma, Proc. Akad. Wet. Amst., 29, 993; 1926.

\title{
New Physics Building at the National Physical Laboratory.
}

\author{
By Dr. G. W. C. KaYE, O.B.E.
}

$\mathrm{B}$ USHY House at Teddington, which was erected about 1715 by the first Earl of Halifax, a president of the Royal Society and a pupil of Newton, played a not inconsiderable part in the life of the Royal Family of Great Britain. It was, however, destined to fill, after two centuries, an even larger rôle in the life of the nation. In 1900, after many preliminaries, Bushy House was selected as the future home of the National Physical Laboratory, and in 1902 the Laboratory was formally opened by the present King (then Prince of Wales).

Since that date, under the directorship first of Sir Richard Glazebrook and now of Sir Joseph Petavel, a great part of the extensive grounds of Bushy house has been gradually covered by a large collection of build. ings devoted to the requirements of the various departments of the Laboratory. During the last few years, these buildings have overflowed on to land acquired for the purpose in the proximity of Bushy Park. But for more than a quarter of a century, physies, the most comprehensive department of the Laboratory, which indeed gives its name to the whole, continued to be inadequately accommodated partly in Bushy House and partly in a number of converted dwelling-houses on the outskirts of the grounds.

Plans for a new physics building were first got out in 1924, and a design prepared by Mr. F. A. Llewellyn, of H.M. Office of Works, was exhibited at the Royal Academy in 1927. The proposed building had a frontage of 295 feet with wings 135 feet in length, forming three sides of a rectangle. The construction

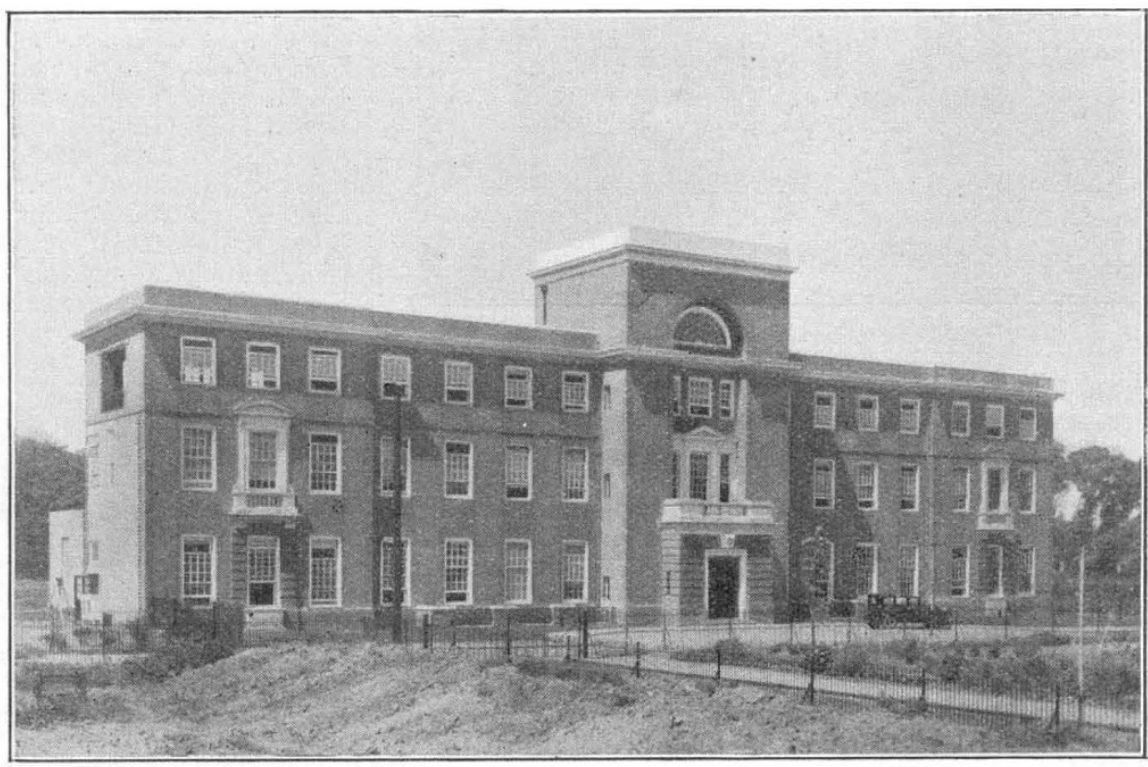

FIG. 1.

of the central portion of the building was begun in January 1929, and the formal opening by Sir $F$. Gowland Hopkins, president of the Royal Society and chairman of the General Board of the Laboratory, took place on June 23 last.

The site of the building, which abuts on Bushy Park on two sides, enjoys immunity from traffic noises and vibrations. The structure is mainly of

No. 3225 , VoL. 128] 
heavy brickwork, which was preferred to a steelframe building on the score of transmission of noise and tremor. The outer walls are of Crowborough bricks with Daneshill brick and Portland stone dressings.

As will be seen from Fig. I, the completed portion of the building (of which the frontage is 180 feet) is mainly of three stories, with a central tower. Each storey is wholly on one level. There is a small basement for special purposes. Behind the main block are workshops, industriallaboratories, store-rooms, boilers, etc., all of ono storey and semi-isolated from tho main building. A large door in the rear of the building is provided with a crane and permits the ready unloading of heavy equipment and stores direct from lorries.

The building is planned on a system of units, all

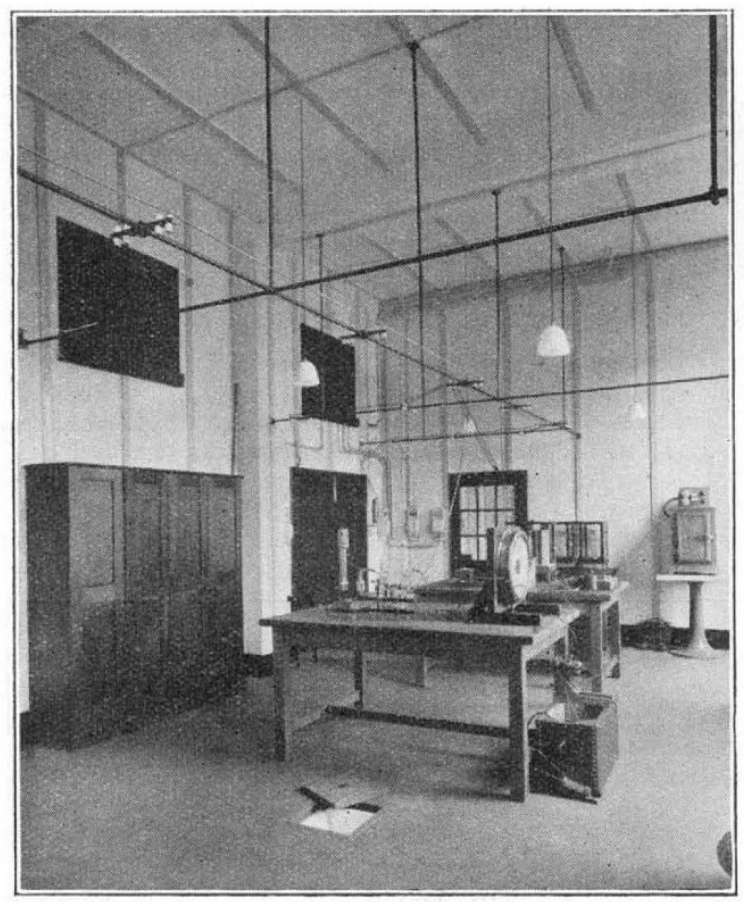

FIG. 2.

partition walls being non-structural, to facilitate rearrangement of rooms should the necessity arise. In general, the rooms measure about $18 \mathrm{ft}$. from back to front, the length being either $10 \mathrm{ft}$., $20 \mathrm{ft}$., or $30 \mathrm{ft}$. The heights of the rooms are $16 \mathrm{ft}$., $14 \mathrm{ft}$., and $12 \mathrm{ft}$. on the ground, first, and second floors respectively. In all cases the floors are of concrete, covered with thick cork carpet. Vertical wooden battens are provided at about $3 \mathrm{ft}$. intervals throughout the walls and ceilings to facilitate the erection of equipment and apparatus. Windows can be quickly darkened by lightproof blinds. Joinery throughout the building is of stained and polished British Columbian pine, except in the entrance hall and landings, where teak has been used.

The whole of the service mains (electricity, gas, water, etc.) are located in spacious horizontal ducts over the corridors. These ducts, which permit a man to walk along them, communicate with each other by vertical ducts and with the various rooms by doors at $10 \mathrm{ft}$. intervals. The distribution of the several services to the experimental tables is completed in each room by the aid of an overhead light steel tubular framework provided with insulators for electric cables, and clips for piping, etc. Thus all the services can be brought immediately above a particular apparatus, the lay-out being much facilitated by the use throughout of movable tables rather than of fixed benches. 'The freedom so gained is enhanced by the provision of sinks let into the floors and provided with loose wooden covers. 'The usual sinks are, of course, also provided. Many of these details are shown in Fig. 2, which illustrates ono of the laboratories.

The electrical services, which are clearly identified by a colour scheme of labels, include 230 -volt A.C. at 50 cycles, 240 -volt D.C., 110 -volt D.C., and 110 volts from a 400-ampere-hour battery. The mains leading from the ducts in the various rooms are connected to 30 -ampere switch fuses on the walls, though in the industrial laboratory provision is made for heavier currents.

A system of small service trolleys (of the dinnerwaggon type), which can be readily transported about the building, provides sets of accumulators giving low voltage D.C. for steady current work. Experience has shown that this meets the present-day requirements of the Department more satisfactorily than the usual system of split-voltage battery mains. The trolley system is also extended to sets of high-voltage lightcurrent accumulators, and to heavy, costly, or specialised instruments which are only occasionally required by a particular experimenter.

Access to the different floors and the flat roof (which is designed to permit open-air experimental work) is gained by a staircase and passenger lift in the central tower, which also contains an experimental well $70 \mathrm{ft}$. deep provided with observation platforms.

As at present arranged, the ground floor of the building is devoted largely to investigations on heat: for example, hygrometry, thermal conductivity of metals, refractories, building materials, etc., specific heats of gases, low-temperature research, work for the Engineering Committee of the Food Investigation Board, including a wind tunnel for measuring the exchange of heat between brine-cooled pipes and air passing outside them. There is also a large 200kilovolt constant-potential generator for operating $\mathrm{X}$-ray tubes used for purposes of 'dosage' and intensity measurements.

The first floor contains the administrative offices, library, etc., and laboratories devoted to investigations in atomic physics, including work on single metal crystals.

The second floor is given over largely to researches on sound: for example, the measurement of noise, the absolute measurement of sound, the calibration of microphones, and the acoustics of buildings. There are large, heavily lagged enclosures to facilitate such work. On this floor also is housed the photographic section of the Laboratory and the departmental drawing office. The end rooms on this floor can have one side opened wide to the outer air should the necessity arise.

The basement affords accommodation for constanttemperature rooms, a reverberation chamber for measurements of acoustical coefficients of absorption, and equipment for photographing sound pulses and water ripples. There are store-rooms in the basement for housing records and special equipment and material, such as radium. The Laboratory, it will be recalled, is responsible for the custody, distribution, and testing of radium for the National Radium Trust and Radium Commission. Facilitios are also provided in the basement for projecting cinematograph films.

$$
\text { No. 3225, VoL. 128] }
$$


The part of the building already constructed will house the Heat and General Physics Section of the Physics Department, with part of the radiology and sound work. It is hoped during the next few years that sanction will be obtained for the erection of the wings, so that the remainder of the Radiology Section and the temperature standardisation work can be transferred from the dwelling-houses and other buildings in which they are at present accommodated. The quadrangle will be completed by the Acoustics Building, the erection of a section of which has recently been approved.

\section{The Pulp-Wood Market in the United States.}

CNDER the arresting headline "Russia seizes Canada's Market", the Monetary Times of Toronto (Jan. 2, 1931) discusses the position of the pulp-wood market, a position which is not without interest for Europe. In 1924, under the heading "The Mistaken Idea that Canada has a Monopoly in Wood ", the Canadian Pulpwood Association in a memorandum to the Royal Commission on Pulpwood wrote: "Contrary to the prevailing idea, it must not be overlooked that if the American is forced to turn away from Canada for raw materials, he will find that we have not by any means a monopoly. For instance, wood from Russia, in large quantities, is already freely quoted, by substantial concerns, for delivery at Atlantic seaports. If the U.S. operator has the Canadian door shut in his face, he will naturally consider it to his interest to encourage forestry conservation and development intensively in the United States to ensure independence as far as possible."

The memorandum went on to point out that research would be stimulated, that so far as possible existing American hardwoods would be utilised, and that already there had been a remarkable development in the use of the long-leaf southern pine in the kraft industry. In short, that there was a possibility that, in the attempt to take advantage of America's extremity by the threat of pulp-wood export restrictions, Canada might find that she had jeopardised a valuable trade connexion in paper products, encouraged her chief customer to develop her own resources, whilst unconsciously encouraging her trade with other countries.

To-day these predictions are coming true. America has been busily engaged in investigating every source of pulp-wood supply, an absolute necessity to her, owing to her enormous consumption of pulp. One of the new sources of supply has proved to be Russia. This year, Russian shipments of the highest quality of wood, amounting to some 300 cords, are being delivered in the eastern States at the same price as Canadian wood. Further, Canada gave transportation preference to the Russian wood; for the latter, landed at the Canadian ports of Sorel or Three Rivers, was for a time carried to the United States by Canadian railways at lower freight rates than these railways gave to Canadian wood for precisely the same movement.

The other possibility predicted, that America would undertake research with the object of endeavouring to make use of materials of her own not previously utilised for the pulp trade, has also been verified by the already mentioned development of the long-leafed southern pine in the kraft industry; and there is another interesting outcome. Dr. C. H. Herty, former president of the American Chemical Society, recently announced to the Atlanta Chamber of Commerce that he had succeeded in producing high grade newsprint paper from southern slash pine, cooked in the same digester and under the same conditions as spruce. The importance of this research work becomes evident when it is understood that there are vast reserves of this timber in the southern States, and that this variety of southern pine had always been regarded as the least capable of producing regular newsprint.

The above description of the present position in the pulp industry in the New World carries some important lessons for Europe. It displays the close and accurate study made of world-wide forest resources and the thorough knowledge of the pulp-wood industry which exists on the other side of the Atlantic. It also throws a strong light on the attitude taken up and ideas expressed since the War in some quarters in Britain upon the small influence the Russian coniferous forests were capable of exerting on the markets.

\section{University and Educational Intelligence.}

LONDON.-The degree of D.Sc. has been conferred on the following: W. Youngman, for a thesis entitled "Further Studies in the Cytology of the Hibiscex", with two subsidiary contributions; S. E. Hollingworth, for a thesis entitled "The Glaciation and Physiographic Development of the Eden Catchment Basin West of that River, and the Drumlins of Edenside and the Solway Basin ", with two subsidiary contributions ; Lin. L. Lee (Rothamsted Experimental Station), for a thesis entitled "The Influence of Geology and Climates on Soil Types" (Jour. S.-E. Agric. Coll., June 1931); A. N. Puri (Rothamsted Experimental Station), for a thesis entitled. "Studies in Soil Colloids" (Memoirs of Dept. of Agriculture, 1930; Soil Science, 1930-31); A. J. Maslen (Chelsea Polytechnic), for a thesis entitled "The Structure of Mesoxylon Platypodium and Mesoxyliodes" (Annals of Botany, July 1930); L. R. Underwood (Imperial College-City and Guilds College and East London College), for a thesis entitled "The Combustion of an Oil Jet in an Engine Cylinder".

THE following fellowships for the year 1931-32 have been awarded by the Salters' Institute of Industrial Chemistry and approved by the Court of the Salters' Company : J. L. Sweeten (St. Catherine's College, Cambridge) and Norman Stuart (Imperial College, London). Fellowships have been renewed to: D. L. Hodge (Imperial College, London), D. J. Branscombe (University College, Exeter), J. Hofton (Caius College, Cambridge), and H. G. Simpson (East London College). The Salters' Institute has also awarded one hundred and thirteen grants-in-aid to young men and women employed in chemical works, to facilitate their further studies.

The Ramsay Memorial Fellowship Trustees have made the following awards of new fellowships for the year 1931-32: Dr. B. K. Blount, a fellowship of $£ 300$, tenable for two years, at the University of Oxford; Mr. Ragnar Ericson, a Swedish fellowship of $£ 300$, tenable for two years, at the Imperial College, London; Dr. George Karagunis, a Greek fellowship of $£ 400$, tenable for one year, at University College, London; Dr. J. Lens, a Netherland fellowship of $£ 300$, tenable for two years, at University College, London; Dr. Y. Urushibara, a Japanese fellowship of $£ 400$, tenable for two years, at University College, London. The Trustees have renewed the following fellowships for the year 1931--32: Mr. W. R. Angus (British fellow), University College, London, and Dr. James Bell (Glasgow fellow), University College, London. 